5. McAllister JD, Gnauck KA. Rapid sequence intubation of pediatric patient. Pediatr Clin North Am. 1999;46:1249-84.

6. Blanda M. Emergency airway management. Emerg Med Clin North Am. 2003;21:1-26.

7. Marvez-Valls E, Houry D, Ernst AA, Weiss SJ, Killeen J. Protocol for rapid sequence intubation in pediatric patients: a four-year study. Med Sci Monit. 2002;8:CR229-34.

8. Kramer DC, Grass G. Challenges facing the anesthesiologist in the emergency department. Cur Opinion Anaesthesiol. 2003; 16:409-16.

9. Sagarin MJ, Chiang V, Sakles JC, Barton ED, Wolfe RE, Vissers $\mathrm{RJ}$, et al. Rapid sequence intubation for pediatric emergency airway management. Pediatr Emerg Care. 2002;18:417-23.

10. Walls RM. Rapid-sequence intubation in head trauma. Ann Emerg Med. 1993;22:1008-13
11. Sing RF, Rotondo MF, Zonies DH, Schwab CW, Kauder DR, Ross $\mathrm{SE}$, et al. Rapid sequence induction for intubation by an aeromedical transport team: a critical analysis. Am J Emerg Med. 1998; 16:598-602.

12. Marvez E, Weiss SJ, Houry DE, Ernst AA. Predicting adverse outcomes in a diagnosis-Based Protocol System for Rapid Sequence Intubation. Am J Emerg Med. 2003;21:23-9.

13. Bonow FP, Piva JP, Garcia PC, Eckert GU. Avaliação do procedimento de intubação traqueal em unidades de referência de terapia intensiva pediátricas e neonatais. J Pediatr (Rio J). 2004;80:355-62.

14. Amantéa SL, Piva JP, Zanella MI, Bruno F, Garcia PCR. Acesso rápido à via aérea. J Pediatr (Rio J). 2003;79 Supl 2:S127-38.

\title{
The nutrition specialist's role in choosing special diets
}

\author{
Ary Lopes Cardoso*
}

$\mathrm{W}_{\mathrm{n}}$ in pediatric practice, a responsible medical posture is imperative. The study by Medeiros et al., ${ }^{1}$ published in this Jornal, deserves the readers' attention because it manages to demonstrate how this can and should be achieved.

Countless nutritional risks, the consequences of macro and micronutrient deficiencies, can be run when diets excluding certain foods are adopted. Several authors ${ }^{2-5}$ highlight a series of medium and long term problems, with the greatest emphasis, for patients under two years, accorded to diets excluding cow's milk.

Medeiros et al. demonstrate the nutritional deficits of the children studied by means of anthropometric data and by listing the intake of macro and micronutrients, especially of calcium. Irrespective of the results, the great merit of this work is its demonstration of the value of multidisciplinary involvement. The participation of the doctor, in conjunction with a nutritionist together with the social assessment are fundamental to guiding the choice of diet to that which most adequately substitutes the excluded items.

* PhD. Assistant physician; Chief of the Nutrology Unit, Instituto da Criança do Hospital das Clínicas, Faculdade de Medicina, Universidade de São Paulo (USP), Brazil.

Suggested citation: Cardoso AL. The nutrition specialist's role in choosing special diets. J Pediatr (Rio J). 2004;80:343-4.
Non-compliance with medical prescriptions has become a constant reality for Brazilian pediatricians. This is most notorious when the subject is exclusion diets. Nutritional risks are run, ${ }^{6}$ becoming more serious to the extent that they remain undetected ${ }^{7}$ or uncorrected. Some examples of risk situations, 8,9 and possibly even of immediate severity ${ }^{10}$ in which exclusion diets are imposed, have been described and discussed in the light of their nutritional aspects in work previously published in this Jornal.

Unfortunately, social, cultural and economic realities are the primary determinant factors in poor compliance with exclusion diet prescriptions. This is often translated into the diet being prepared inadequately, with insufficient (or excessive) nutrient intake; the allergic and/or inflammatory process being sustained by transgressions, allergy caused by substitute foods and varying degrees of malabsorption, both of macro and micronutrients, among others.

The participation of the nutrition specialist is necessary to the discussion and planning of care when an exclusion diet is being considered. Among other reasons are the capacity to assess nutritional requirements from anthropometric data and other body evaluation methods, to interpret the nutritional survey developed in conjunction with the nutritionist and for knowledge on the characteristics of the new ingredients that are contained in the new formulae and complete diets that are periodically launched onto the market in arithmetic progression. ${ }^{11,12}$ 


\section{References}

1. Medeiros LCS, Speridião PGL, Sdepanian VL, Fagundes-Neto U, Morais MB. Ingestão de nutrientes e estado nutricional de crianças em dieta isenta de leite de vaca e derivados. J Pediatr (Rio J). 2004;80:363-70.

2. Henriksen C, Eggesbo M, Halvorsen R, Botten G. Nutrient intake among two-year-old children on cow's milk-restricted diets. Acta Paediatr. 2000;89:272-8.

3. Arvola T, Holmberg-Marttila D. Benefits and risks of elimination diets. Ann Med. 1999;31:293-8.

4. Mofidi S. Nutritional management of pediatric food hypersensitivity. Pediatrics. 2003;111:1645-53.

5. Christie L, Hine RJ, Parker JG, Burks W. Food allergies in children affect nutrient intake and growth. J Am Diet Assoc. 2002;102:1648-51.

6. Palma D. Avaliação da condição nutricional. J Pediatr (Rio J). $1995 ; 71: 125$.
7. Mello ED. O que significa a avaliação do estado nutricional. J Pediatr (Rio J). 2002;78:357-8.

8. Hamamoto LA, Cardoso AL, Marques HS, Gomes C. Balanço de energia em lactentes filhos de mães soropositivas para o HIV. J Pediatr (Rio J). 2000;76:119-24.

9. Alves GMS, Morais MB, Fagundes-Neto U. Estado nutricional e teste do hidrogênio no ar expirado com lactose e lactulose em crianças indígenas terenas. J Pediatr (Rio J). 2002;78:113-9.

10. Machado RS, Kawakami E, Goshima S, Patricio FR, FagundesNeto U. Gastrite hemorrágica por alergia ao leite de vaca: relato de dois casos. J Pediatr (Rio J). 2003;79:363-8.

11. Walker-Smith J, Murch S. Gastrointestinal food allergy. In: John A Walker-Smith, editor. Diseases of the Small Intestine in Childhood. 4th ed. ISIS - Medical Media; 1999. p. 205-234.

12. Boehm G, Fanaro S, Jelinek J, Stahl B. Prebiotic concept for infant nutrition. Acta Paediatr Suppl. 2003;91:64-7.

\title{
Cystic fibrosis in Brazil: the pediatrician's turn
}

\author{
Paulo A. M. Camargos*
}

Lessons learnt: undeniable advances, multiple and complex challenges. Also multiple are the teachings of the group from Campinas contained in their article published in this issue of the Jornal de Pediatria; they toast us with a wide-ranging, competent and provocative report on their sample of 104 cystic fibrosis patients. ${ }^{1}$ Most probably the richest work in specialized Latin-American literature.

For these reasons, the aspects to be analyzed are equally multiple. An agreeable, although to a certain extent ungrateful, task, since editorial space, by nature, is limited. Limitation does not conjugate well with multiplicity and so we are obliged to isolate those aspects that will be analyzed with a view to the general pediatrician and those that work in related subspecialties (pulmonology, gastroenterology, nutrology and others), also pediatricians first and foremost. With space at a premium, we, intentionally, choose two items: survival and age at diagnosis because both reflect on the (lack of) care that patients have been receiving, and which is not limited to this, esteemed, center of excellence.

* Full professor, Department of Pediatrics, School of Medicine, Universidade Federal de Minas Gerais (UFMG) and Chief of the Pediatric Pulmonology Unit, Hospital das Clínicas, Universidade Federal de Minas Gerais (UFMG), Belo Horizonte, MG, Brazil.

Suggested citation: Camargos PAM. Cystic fibrosis in Brazil: the pediatrician's turn. J Pediatr (Rio J). 2004;80:344-6.
In survival, we have made progress. Brazilian CF centers have participated in two collaborative studies, ${ }^{2,3}$ that covered the periods 1979-1989 and 1960-1989 and onto which were enrolled respectively, 743 and 1,827 patients, from four and ten Latin-American countries. Mean survival age at death was just 6-7 years. Brazilian centers integrated the both studies and the mean age of patients who were still in follow-up from the first period (19791989) was just 6.4 years. $^{2}$ Another Brazilian study covered a period starting before and ending after these two studies, and performed at a service that also took part in the two previously mentioned studies, found that for the period 1970-1994, mean survival had jumped to 12.6 years. ${ }^{4}$ Another pleasant surprise is afforded us by the cohort from Campinas: during the decade 1990-2000, median survival reached a new level of 18.4 years of survival age after diagnosis, ${ }^{1}$ an estimate which is equivalent to figures from the United States in the 80s. As the authors explain, life expectancy with this condition in industrialized nations is currently around 31.6 years. ${ }^{1}$ Therefore, we could ask: would our general pediatricians win our patients extra years, through greater proximity and more frequent consultations, if there was a directed effort in combination with the sub-specialists?

With respect of age at diagnosis, we have remained parked. For the two Latin American cohorts and the cohort evaluated by the Campinas team, average age at diagnosis was, respectively, greater than 3-4 years ${ }^{2,3}$ and 4 years and 2 months. ${ }^{1}$ Notwithstanding, it is enough to observe in the article that is the subject of this Editorial that $81.1 \%$ of the 